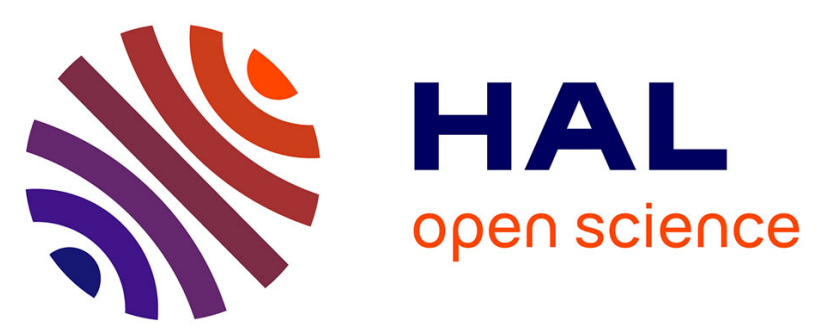

\title{
Induction Of The Ras Activator Son Of Sevenless 1 By Environmental Pollutants Mediates Their Effects On Cellular Proliferation
}

Stéphane Pierre, Anne-Sophie Bats, Aline Chevallier, Linh-Chi Bui, Ariane

Ambolet-Camoit, Michèle Garlatti, Martine Aggerbeck, Robert Barouki, Xavier Coumoul

\section{To cite this version:}

Stéphane Pierre, Anne-Sophie Bats, Aline Chevallier, Linh-Chi Bui, Ariane Ambolet-Camoit, et al.. Induction Of The Ras Activator Son Of Sevenless 1 By Environmental Pollutants Mediates Their Effects On Cellular Proliferation. Biochemical Pharmacology, 2010, 81 (2), pp.304. 10.1016/j.bcp.2010.10.003 . hal-00649887

\section{HAL Id: hal-00649887 https://hal.science/hal-00649887}

Submitted on 9 Dec 2011

HAL is a multi-disciplinary open access archive for the deposit and dissemination of scientific research documents, whether they are published or not. The documents may come from teaching and research institutions in France or abroad, or from public or private research centers.
L'archive ouverte pluridisciplinaire HAL, est destinée au dépôt et à la diffusion de documents scientifiques de niveau recherche, publiés ou non, émanant des établissements d'enseignement et de recherche français ou étrangers, des laboratoires publics ou privés. 


\section{Accepted Manuscript}

Title: Induction Of The Ras Activator Son Of Sevenless 1 By Environmental Pollutants Mediates Their Effects On Cellular Proliferation

Authors: Stéphane Pierre, Anne-Sophie Bats, Aline Chevallier, Linh-Chi Bui, Ariane Ambolet-Camoit, Michèle Garlatti,

Martine Aggerbeck, Robert Barouki, Xavier Coumoul

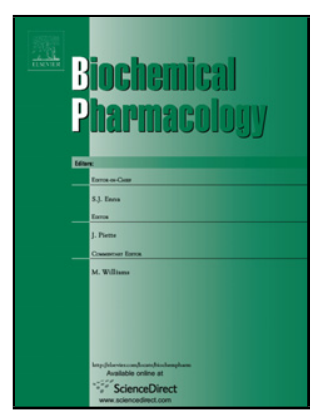

PII:

S0006-2952(10)00759-8

DOI: doi:10.1016/j.bcp.2010.10.003

Reference: BCP 10735

To appear in: $\quad B C P$

Received date: $\quad 12-8-2010$

Revised date: $\quad 3-10-2010$

Accepted date: $\quad$ 5-10-2010

Please cite this article as: Pierre S, Bats A-S, Chevallier A, Bui L-C, Ambolet-Camoit A, Garlatti M, Aggerbeck M, Barouki R, Coumoul X, Induction Of The Ras Activator Son Of Sevenless 1 By Environmental Pollutants Mediates Their Effects On Cellular Proliferation, Biochemical Pharmacology (2010), doi:10.1016/j.bcp.2010.10.003

This is a PDF file of an unedited manuscript that has been accepted for publication. As a service to our customers we are providing this early version of the manuscript. The manuscript will undergo copyediting, typesetting, and review of the resulting proof before it is published in its final form. Please note that during the production process errors may be discovered which could affect the content, and all legal disclaimers that apply to the journal pertain. 
Title page

INDUCTION OF THE RAS ACTIVATOR SON OF SEVENLESS 1 BY ENVIRONMENTAL POLLUTANTS MEDIATES THEIR EFFECTS ON CELLULAR PROLIFERATION

Stéphane Pierre ${ }^{1,2,}$, Anne-Sophie Bats ${ }^{1,2,3,}$, Aline Chevallier ${ }^{1,2}$, Linh-Chi Bui ${ }^{1,2}$, Ariane Ambolet-Camoit ${ }^{1,2}$, Michèle Garlatti ${ }^{1,2}$, Martine Aggerbeck ${ }^{1,2}$, Robert Barouki $1,2,4$, Xavier Coumoul ${ }^{1,2, \dagger}$

${ }^{1}$ INSERM UMR-S 747, Toxicologie Pharmacologie et Signalisation Cellulaire, 45 rue des Saints Pères, 75006 Paris France

${ }^{2}$ Université Paris Descartes, Centre universitaire des Saints-Pères, 45 rue des Saints Pères, 75006 Paris France

${ }^{3}$ AP-HP, Hôpital Européen Georges Pompidou, Service de Chirurgie Gynécologique Cancérologique, 75015 Paris France

${ }^{4}$ AP-HP, Hôpital Necker-Enfants Malades, service de biochimie métabolique, Paris, France

$\$$ These authors contributed equally to this work.

Running title : Regulation of Ras activator SOS1 by dioxin.

${ }^{\dagger}$ Address correspondance to : Xavier Coumoul, INSERM UMR-S 74745 rue des Saints Pères 75006 Paris France Phone: +331428633 59 Fax : +33 142863868 E-mail: xavier.coumoul@parisdescartes.fr 
Abstract

TCDD (2,3,7,8-TetraChloroDibenzoDioxin), a highly persistent environmental pollutant and a human carcinogen, is the ligand with the highest affinity for the Aryl Hydrocarbon Receptor ( $\mathrm{AhR}$ ) that induces via the $\mathrm{AhR}$, xenobiotic metabolizing enzyme genes as well as several other genes. This pollutant elicits a variety of systemic toxic effects, which include cancer promotion and diverse cellular alterations that modify cell cycle progression and cell proliferation. Large-scale studies have shown that the expression of Son of Sevenless 1 (SOS1), the main mediator of Ras activation, is one of the targets of dioxin in human cultured cells. In this study, we investigated the regulation of the previously uncharacterized SOS1 gene promoter by the AhR and its ligands in the human hepatocarcinoma cell line, HepG2. We found that several environmental pollutants (AhR ligands) induce SOS1 gene expression by increasing its transcription. Chromatin Immunoprecipitation experiments demonstrated that the AhR binds directly and activates the SOS1 gene promoter. We also showed that dioxin treatment leads to an activated Ras-GTP state, to ERK activation and to accelerated cellular proliferation. All these effects were mediated by SOS1 induction as shown by knock down experiments. Our data indicate that dioxin-induced cellular proliferation is mediated, at least partially, by SOS1 induction. Remarkably, our studies also suggest that SOS1 induction leads to functional effects similar to those elicited by the wellcharacterized oncogenic Ras mutations.

Keywords : Dioxin, AhR, SOS1, Ras, Cell proliferation 


\section{Introduction}

The Ras signalling pathway is involved in cell growth and differentiation. Mutations in the Ras proto-oncogene have been described in a large variety of human malignancies [1]. These mutations result in a constitutively active Ras protein, which is one of the most common Ras dysregulations in cancers [1,2]. Three different Ras genes encoding the H-Ras, $\mathrm{K}-\mathrm{Ras}$ and N-Ras $21 \mathrm{kDa}$ proteins were discovered 30 years ago [1, 3]. The activated Ras proteins physically associate with and activate Raf-1, a serine/threonine kinase which triggers a kinase cascade that results in the activation of the extracellular signal-regulated protein kinases (ERKs of the MAPK family). Ras acts as a functional hub by activating multiple downstream pathways that participate in cell growth and differentiation. The activity of Ras is regulated by two sets of proteins: guanine-nucleotide exchange factors (GEFs) and GTPaseactivating proteins (GAPs). GEFs stimulate the release of the Ras bound GDP which then allows GTP to bind and activate Ras. Conversely, GAPs stimulate Ras GTPase activity and lead to the basal GDP-bound state.

Several pathways, which lead to the active Ras state, have been described in mammalian cells. The best-characterized pathway employs the activation of tyrosine kinase receptors to elicit binding of various proteins to the phosphorylated receptor, most notably the growth factor receptor bound 2 (Grb2) protein bound to the guanine nucleotide exchange factor SOS1. The complex is targeted to the plasma membrane, allowing the GEF function of SOS1 to activate Ras by GDP/GTP exchange [4-6]. SOS1 can activate other GTP-binding proteins [4] and other effectors also control Ras activity. The most extensively characterized non-physiological conditions under which increased SOS activitiy has been observed result from gain of function mutations. For example, SOS1 mutations have been described in the Noonan syndrome, a developmental disorder that is characterized by short stature, facial dysmorphia, congenital heart defects and skeletal anomalies [7, 8]. These gain of function mutations, which lead to the activation of Ras and were the first examples of activating GEF mutations associated with human disease. Surprisingly, the implications of increased expression of SOS proteins have not been addressed and little is known about the regulation of the gene promoter.

Dioxin is a member of the PolyChlorinated dibenzo Dioxins (PCDD) family which is a class of highly persistent environmental contaminants. 2,3,7,8-TetraChloroDibenzoDioxin (TCDD), the most extensively characterized dioxin, has been classified in 1997 as a "human carcinogen" by the International Agency for Research on Cancer (IARC) [9]. This pollutant is the ligand with the greatest affinity for the Aryl Hydrocarbon Receptor (AhR). TCDD via the 
$\mathrm{AhR}$, induces various toxicities including chloracne, wasting syndrome, teratogenicity, immunotoxicity, neurotoxicity, tumor promotion and carcinogenesis [10]. The AhR is a cytosolic, ligand-activated transcription factor which, upon activation, translocates to the nucleus where it forms a heterodimer complex with AhR Nuclear Translocator (ARNT). This complex binds to specific Xenobiotic Responsive Elements (XRE) which are characterized by a 5'-GCGTG-3' consensus core and induces specific target genes which include xenobiotic metabolizing enzymes (XME) such as the cytochrome P450 (CYP) 1 family [11]. In addition to detoxification functions, the activation of this receptor has been shown to elicit diverse cellular effects including cell proliferation [12,13]. These cellular alterations might mediate part of the long-term toxicity of the AhR ligands in animals and humans [14]. Indeed, AhRnull mice display several defects of development and proliferation including thymus and liver hypotrophy [15]. Numerous studies using AhR defective cells or AhR invalidating strategies have clearly established a role for this receptor in cell cycle regulation and proliferation [16]. The dysregulation of these cellular pathways may disrupt normal fetal development and favor cancer progression. The AhR gene targets that are involved in the proliferative effects of this receptor are not completely identified. To this end, we have examined large-scale toxicogenomic analyses of dioxin effects and focused on regulatory proteins that control cellular growth, in particular, the main mediator of Ras activation, SOS1.

In the present work, we investigated, for the first time, the regulation of the previously uncharacterized SOS1 gene promoter by the AhR and its ligands in the human hepatocarcinoma cell line, HepG2. We show that several environmental pollutants (AhR ligands) induce SOS1 gene expression via increased transcription. Moreover, considering the critical role of SOS1 in controlling Ras activity, we also demonstrate that induction of SOS1 by AhR ligands leads to a predominant Ras-GTP state, to MAPK activation and to cell growth. The results point towards SOS1 gene induction as being a critical step for the carcinogenic effects mediated by dioxins. 


\section{Materials and methods}

2.1. Cell Culture. Human hepatocarcinoma HepG2 cells were cultured in Dulbecco's minimal essential medium (DMEM, Invitrogen, Cergy-Pontoise, France) supplemented with nonessential amino acids and containing $10 \%$ fetal bovine serum, $200 \mathrm{U} / \mathrm{mL}$ penicillin, 50 $\mu \mathrm{g} / \mathrm{mL}$ streptomycin (Invitrogen) and $0.5 \mathrm{U} / \mathrm{mL}$ amphotericin B (Bristol-Myers Squibb Co., Stamford, $\mathrm{CT}$ ) at $37^{\circ} \mathrm{C}$ in a humidified atmosphere of $5 \% \mathrm{CO}_{2}$ in air. The day before with the addition of various concentrations of TCDD, cells were cultured in DMEM without phenol red and supplemented with 3\% charcoal-treated (desteroidized) calf serum. Cells were maintained in this medium during all the treatments except for the proliferation studies. TCDD was purchased from LCG Promochem (Molsheim, France). Benzo(a)pyrene, and quercetin were purchased from Sigma-Aldrich (St Louis, United States).

\subsection{RNA extraction, reverse transcription and quantitative RT-PCR. Total RNAs} were extracted using the RNeasy mini kit (Qiagen, Les Ulis France) and reverse transcription was performed with each RNA sample using the cDNA High-Capacity Archive kit (Applied Biosystems, Courtaboeuf, France) as previously described [17] . Specific oligonucleotides were designed using the OLIGO Explorer software (Molecular Biology Insights, Inc., Cascade, CO). Gene specific primers used for the real time PCR were: SOS1: forward 5'TGAGAGGCAACAGAAAGAGC-3' and reverse 5'-GAGAAGGGAAATGAAATGGG-3'; AhR: forward 5'-ACATCACCTACGCCAGTCGC-3' and reverse 5'TCTATGCCGCTTGGAAGGAT-3'; RPL13A: forward 5 CCTGGAGGAGAAGAGGAAAGAGA-3' and reverse 5 GAGGACCTCTGTGTATTTGTCAA-3'. Oligonucleotides were obtained from (Qiagen). Quantitative RT-PCR was carried out in a $10 \mu \mathrm{L}$ reaction volume containing $40 \mathrm{ng}$ of cDNA, $300 \mathrm{nM}$ of each primer and ABsolute ${ }^{\mathrm{TM}}$ QPCR SYBR ${ }^{\circledR}$ Green (Abgene, Villebon sur Yvette, France). Quantitative RT-PCR measurements were performed on an ABI Prism 7900 Sequence Detector system (Applied Biosystems). PCR cycles consisted of the following steps: Taq activation $\left(15 \mathrm{~min}, 95^{\circ} \mathrm{C}\right)$, denaturation $\left(15 \mathrm{~s}, 95^{\circ} \mathrm{C}\right)$ and annealing and extension $\left(1 \mathrm{~min}, 60^{\circ} \mathrm{C}\right)$. The threshold cycle $(\mathrm{Ct})$, which is inversely correlated to the amount of target mRNA, was measured as the number of cycles for which the reporter fluorescent emission first exceeds the background. The relative amounts of mRNA were estimated using the $\Delta \Delta \mathrm{Ct}$ method with RPL13A as reference. 
2.3. Immunoblotting. Whole cell lysates were prepared as previously described [17]

from HepG2 cells with M-PER®, Mammalian Protein Extraction Reagent, containing protease and phosphatase inhibitor cocktails (Sigma-Aldrich, St Louis, United States). Equal amounts of total protein were separated by SDS-PAGE and transferred onto nitrocellulose membranes (GE Healthcare, Orsay, France). The membranes were probed with primary antibodies recognizing SOS1 (Upstate, Molsheim, france, 07-337, 1:2000), Actin (Abcam, Paris, France ab37063, 1:10000), AhR (Abcam, ab2770, 1:1000), ERK-Phosphorylated (Cell signaling, Saint Quentin en Yvelines, France 9101, 1:2000), ERK (Cell signaling, 4695, 1:2000) and Ras (Upstate 05-516, 1:10000). Immunoreactive bands were detected with X-ray film using alkaline phosphatase-linked secondary antibody (Applied biosystems, T2191 or T2192, 1:20000) and an enhanced chemiluminescence system CDP-Star® (Applied biosystems). Relative Quantification of the amount of immunreactive material was performed with ImageJ freeware (http://rsb.info.nih.gov/ij/).

2.4. SOS1 mRNA half-life measurement. On day 1, HepG2 cells were seeded at 400 000 cells/well (in 6-well plates) in complete DMEM medium (see above). On day 2, cells were washed with PBS and the medium was replaced by red phenol-free DMEM supplemented with $3 \%$ desteroidized fetal bovine serum, $200 \mathrm{U} / \mathrm{mL}$ penicillin, $50 \mu \mathrm{g} / \mathrm{mL}$ streptomycin and $0.5 \mathrm{mg} / \mathrm{mL}$ amphotericin B. Then TCDD dissolved in medium $(1 \mu \mathrm{M})$. Fifty $\mu \mathrm{L}$ was added to the cells medium to give a final concentration of $25 \mathrm{nM}$. Twenty four hours later (on Day 3), cells were treated with $100 \mu \mathrm{M}$ DRB (5,6-dichloro-beta-D ribofuranosyl benzimidazole, Sigma-Aldrich) and lysates were extracted at 0, 2, 4, 6, 10 and 12 hours after the addition of DRB using the RNeasy mini kit (Qiagen) Quantitative real-time PCR was then performed.

2.5. In silico analysis and primer extension. In silico analysis was performed with MatInspector $^{\circledR}$ software (Genomatix, Munich, Germany) to identify all the potential consensus responsive elements in the promoter. For the primer extension study, total RNAs were extracted using the RNeasy mini kit (Qiagen) as described. Primer extension experiments were performed with the Primer Extension System-AMV Reverse Transcriptase kit (E3030, Promega, Charbonnières les Bains, France). Positive and negative controls are provided with the Kit from Promega. A specific primer was designed (+100 5'GGGACCCCGCTTCCCGGCCGCAGC-3' +123) (+ 1 refers to translation start site) and labeled with $\left[\gamma^{32}\right.$ P]ATP (Easytides, BLU502A001MC, Perkin-Elmer, Courtaboeuf, France). 
The reverse transcription product was separated on a denaturing acrylamide gel. After migration, radioactive bands were visualized with a phosphorimager (STORM 580).

2.6. siRNA transfection. The day before the transfection, HepG 2 cells $\left(4 \times 10^{5}\right.$ cells / well) were seeded in 6-well plates. The medium was replaced the day of the transfection by DMEM, without phenol red, supplemented with 3\% charcoal-treated (desteroidized) calf serum. Cells were then transfected with 20 nM SOS1 siRNA, using the Lipofectamine 2000 transfection reagent (Invitrogen) according to the manufacturer's protocol and with $5 \mathrm{nM} \mathrm{AhR}$ siRNA using the HiPerfect transfection reagent (Qiagen) according to the manufacturer's protocol. For SOS1 and AhR experiments, the medium was replaced after $24 \mathrm{~h}$ of incubation at $37^{\circ} \mathrm{C}$ and cells were treated or not with $25 \mathrm{nM}$ TCDD. RNA and protein purification were carried out $48 \mathrm{~h}$ after the transfection. siRNA references and/or sequences (Qiagen) were:

- siSOS1: Hs_SOS1_5_HP Validated siRNA (ref : SI02655121)

- siAhR: Hs_AHR_5_HP Validated siRNA (ref: SI02780148)

- siControl: GFP Custom siRNA (ref: 1027020)

2.7. Reporter assays. pGLuc basic vector (New England Biolabs, Ipswich, MA) was digested with BglII and HindIII restriction enzymes (New England Biolabs). For the construction of the SOS1 promoter (AF 106953) the-2200,+37 region;(+ 1 refers to the translation start site) was amplified using the following primers : -2200 5'CTTAGATCTAAGTGGGGAGTTTTTCAAATGT-3' ${ }^{\prime}-2170$ and $+37 \quad 5^{\prime}$ AAGCTTTCGCTGAAAAACTCGTAGGG-3' +17 . The PCR product was cut with the same restriction enzymes. Transfection experiments were performed as described in siRNA transfection paragraph, using $1 \mu \mathrm{g}$ of plasmid. The empty pGLuc basic vector (New England biolabs) was used as transfection control. Twenty-four hours after the transfection, $50 \mu \mathrm{L}$ supernatant (containing the secreted luciferase) were collected and the medium was changed. The cells were then treated or not with $25 \mathrm{nM}$ TCDD as described above. The supernatant was then harvested at $0 \mathrm{~h}, 6 \mathrm{~h}, 24 \mathrm{~h}$ and $48 \mathrm{~h}$ after TCDD treatment. A luciferase assay (Gaussia) was performed with a New England Biolabs kit (E3300L) and a luminometer (Lumat LB9507, Berthold, Thoiry, France).

2.8. Chromatin Immunoprecipitation. HepG2 cells were seeded into 150-mm-diameter dishes (approximately 20x $10^{6}$ cells per dish) $48 \mathrm{~h}$ before being processed for ChIP as previously described [17]. Treatment with TCDD (25nM) was performed, as described above, 
for 15- and for $45 \mathrm{~min}$. We used a ChIP-grade antibody from BioMol (anti-AhR antibody, Cat SA-210, BioMol, Plymouth Meeting, Pennsylvania, USA) ChIP DNA was analysed by quantitative PCR using the specific primers covering the region between $-984 \mathrm{bp}$ and -801 bp of the human Sos1 promoter region (forward primer: 5'-GGTTTCGTGACAGAGCACCT3' and reverse primer 5'-TAAAGAGGCTCCCCATTGTG 3') and non-specific primers (forward primer: 5'-TGGGGTAGACTGTGGCAGA-3' and reverse primer 5'GGCTAAGGATTCAGCAGCAA-3').

2.9. Ras activity. On day 1 , cells were seeded at approximately 15 million cells per $175-\mathrm{cm} 2$ plate. Twenty-four hours later (day 2), the medium was changed and siRNA SOS 1 transfection was performed (see above). On Day 3, the medium was changed and TCDD $(25 \mathrm{nM})$ was added as previously described. On day 4 , the medium was replaced with a medium without serum containing or not TCCD $(25 \mathrm{nM})$. On day 5 , cells were lysed in Magnesium Lysis Buffer (MLB, Upstate) containing protease and phosphatase inhibitor cocktails (Sigma). Equal amounts of total protein extracts, treated or not, were incubated with Raf-RBD GST beads (Cytoskeleton, Le Perray en Yvelines, France RF-02A), to retain only the active form of Ras, (Ras-GTP) following the manufacturer's recommendations (Upsate). The recovered proteins were separated by SDS-PAGE (see above) and western blots (Ras antibody) were performed. Moreover, we used GTP gamma-S as a positive control and GDP as a negative control (Upstate).

2.10. Cell growth. On day 1, cells were seeded at 30,000 cells / well (in 6-well plates) in complete DMEM medium (see above). On day 4, siRNA SOS1 and siRNA AhR transfection was performed (see above). On day 5, cells were treated with TCDD (25nM) as above. For each condition, the number of cells per well was counted at times corresponding to 0h, $24 \mathrm{~h}$ and $48 \mathrm{~h}$ of TCDD treatment. For cell counting, cells in each well were trypsinised with $150 \mu \mathrm{L}$ of Trypsine-Versene (Invitrogen), which was neutralized, with $150 \mu \mathrm{L}$ of complete medium.

2.11. Statistical analysis. The data result from at least three independent experiments. The results were expressed as the mean \pm standard error. Differences between groups were analyzed by U Mann-Whitney's test (nonparametric comparison of 2 independent series) or $\mathrm{H}$ Kruskal-Wallis's test (nonparametric comparison of $\mathrm{k}$ independent series) followed by a 1- 
factor ANOVA test (parametric comparison of $\mathrm{k}$ independent series). A p-value $<0.05$ was considered as statistically significant.

\section{Results}

TCDD is known to promote cellular proliferation and cell cycle progression in different cellular models. Since several toxicogenomic large-scale studies, including our own, were performed in the human hepatocarcinoma HepG2 cell line and since this cell line exhibits high levels of $\mathrm{AhR}$ expression, we used the HepG2 cells for our gene regulation studies. As will be shown later in this article, TCDD elicited a 20\% increase in the number of cells during the exponential phase of growth. Thus, the HepG2 cells constitute an appropriate model to investigate the molecular mechanisms of TCDD-elicited cellular proliferation.

\subsection{Effect of dioxin treatment on SOS1 mRNA and protein levels in HepG2 cells. In} a large-scale gene expression study, SOS1 mRNA was found to be induced by TCDD [18]. First, we validated those observations in HepG2 cells. We performed kinetic and doseresponse experiments and we extracted both total RNA and total protein. SOS1 expression was assessed using both quantitative real-time PCR (Figures 1A \& C) and immunoblotting (western blots) (Figures 1B \& D). Dose-response experiments showed that TCDD upregulated SOS1 mRNA expression (Figure 1A) and protein level (Figure 1B and supplementary figure 1A). The response was significant for concentrations higher than $10 \mathrm{nM}$ TCDD. Consequently, 25nM TCDD was used in the following experiments. This concentration of TCDD is within the usual concentration range used to treat human cells (5$100 \mathrm{nM}$ ). Figures 1C-D and supplementary figure 1B show that SOS1 was significantly upregulated by $25 \mathrm{nM}$ TCDD in a time-dependent manner. In addition to HepG2 cells, we have also observed a significant up-regulation of SOS1 mRNA in several mouse tissues (C57/B16) following TCDD treatment (Supplementary figure 2). These results indicate that SOS1 is upregulated upon TCDD treatment and suggest that the SOS1 gene might be an AhR transcriptional target.

3.2. SOS1 mRNA and protein induction is AhR-dependent. We examined the contribution of the Ah Receptor using different AhR ligands including TCDD, Benzo(a)pyrene and quercetin (Figure 2A) and a RNA interference knock down strategy (Figures 2B, 2C \& 2D). Figures $2 \mathrm{~A}$ shows that the AhR ligands, $25 \mathrm{nM}$ TCDD and $5 \mu \mathrm{M}$ 
BaP, significantly increased SOS1 mRNA; although an increase in SOS1 mRNA was also observed after treatment of cells with $25 \mu \mathrm{M}$ Quercetin, this increase was not significant. We then knocked down AhR expression using specific siRNA (Fig 2B), which decreased AhR mRNA by approximately 60-70\% (Fig 2B). AhR levels remain knock-downed throughout the time course of the experiment (Supplementary figure 3). Figure 2C and 2D show that AhR siRNA treatment elicited a statistically significant $50 \%$ decrease in both SOS1 mRNA and protein induction by TCDD. In this experiment, we did not expect to completely knock-down AhR levels but we aimed to correlate the relationship between both AhR and SOS1 levels; we observed such a correlation (AhR by the time of treatment, 0h, 50\% decreased levels and SOS1 at the end of the experiment, $50 \%$ decrease) and also a $60 \%$ decrease in CYP1A1 induction which is classically measured to prove AhR activation (data not shown). These experiments demonstrate that the activated AhR regulates SOS1 mRNA and protein levels.

3.3. The SOS1 gene promoter is a direct target of the AhR. To further characterize the mechanism of SOS1 induction by TCDD, we blocked RNA polymerase II with DRB and measured SOS1 mRNA levels upon TCDD treatment, as well as under untreated conditions. Figure 3 shows that the rate of SOS1 mRNA decline was not significantly different in treated and untreated conditions suggesting that a decreased rate of SOS1 mRNA degradation is not involved in the TCDD up-regulation of SOS1 mRNA (Figure 3A). Very recently, the exonintron structure of the SOS1 gene was displayed in the Pubmed Ace View Database. Exon 1 is shown to start 280 bases upstream of the translation start site for the longest variant. Other mRNA variants differing in the length of the 5' ends have been found in different tissues but little information was given on their abundance. To further define the length of the 5' UTR in our cell line model, we performed a primer extension study, which confirmed the presence of a major start site approximately 150 bp upstream from the translation start site, which is in line with the displayed gene structure (data not shown). A minor transcription start site was also observed downstream from the major one, which is not surprising in this GC-rich promoter. Then we performed a MatInspector ${ }^{\circledR}$ analysis of the 2200 base pairs located upstream of the transcription start sites to identify consensus AhR sequences (Xenobiotic Responsive Elements or XRE); Figure 3B shows the positions and the sequences of 2 putative XREs (AhR binding).

Several experiments were carried out in order to determine whether the SOS1 gene promoter is a direct target of the AhR, including luciferase reporter gene assays (Figure 4A and $4 \mathrm{~B}$ ) and Chromatin ImmunoPrecipitation (ChIP) assays using a specific AhR antibody 
(Figure 4C). We subcloned the $(-2200 /+37)$ fragment of the SOS1 gene promoter (which includes the two putative XREs) upstream of the Gaussia luciferase reporter gene. The activity of this gene product can be readily monitored in the medium. Following transfection with this recombinant reporter gene plasmid, HepG2 cells were treated with TCDD and the medium was recovered at different time points for luciferase assay (Figure 4A). A significant increase in luciferase activity can be observed 24 and 48 hours following TCDD treatment. These experiments confirm that the $(-2200 /+37)$ SOS1 gene fragment exhibits promoter activity as compared to the empty vector (Figure 4B), and suggest that this gene promoter fragment mediates part of the inducing effect of TCDD. Similar experiments were performed in control siRNA and AhR-siRNA treated cells (Fig 4B). We observed a similar 2- to 3-fold increase in the activity of the SOS1 gene promoter in siControl-transfected cells upon TCDD treatment. However, basal and induced SOS1 promoter activities were significantly reduced in AhR-depleted cells suggesting a contribution of this receptor to SOS1 gene promoter activation.

Finally, we performed a Chromatin Immuno Precipitation (ChIP) experiment using a SOS1 promoter fragment (-984/-801) to confirm the direct binding of AhR to the endogenous SOS1 gene promoter (Figure 4C). AhR antibody and real-time PCR were used to provide a quantitative measurement of receptor binding. Cells were treated for 15 and 45 minutes with TCDD. Several controls were used for the experiments (inputs, mock antibody). We observed a time-dependent, specific and potent increase of AhR binding to the SOS1 gene promoter. Altogether, these experiments clearly show that the TCDD-mediated transcriptional regulation of the SOS1 gene is related to the rapid direct binding of the AhR to the promoter.

\subsection{TCDD stimulates Ras activity and ERK1/2 phosphorylation through induction} of SOS1. Since the Guanine nucleotide Exchange Factor SOS1 regulates the Ras-MAPK pathway, we hypothesized that increased amounts of SOS1 could lead to the activation of this pathway. Thus, we monitored Ras activity (the active GTP-bound form) and ERK phosphorylation following TCDD treatment of HepG2 cells. To monitor Ras activity, we performed affinity pull-down experiments. Beads grafted with the domain of Raf, which specifically interacts, with the GTP-bound form of Ras were mixed with different cellular extracts. The bound fraction was then eluted and analyzed with a Ras antibody. Figure 5A shows that the active form of Ras was increased following TCDD treatment. In parallel, the phosphorylated fraction of ERK was also increased by TCDD treatment (fig 5B). To assess the implication of SOS1 in these processes, we down-regulated SOS1 expression using a 
specific siRNA and observed a clear decrease of TCDD-induced Ras-GTP levels as shown in figure 5C. SOS1 protein levels remain knocked down throughout the time course of the experiment. These results show that SOS1 is a critical mediator of TCDD-dependent RASMAPK pathway activation. Importantly, for the first time, these observations show that increased amounts of SOS1 are sufficient to activate the downstream pathway indicating that, in HepG2 cells, the amount of SOS1 is limiting. It is noteworthy, however, that the Ras pathway activation by TCDD is delayed as compared to the time course of the response which can be traditionally achieved by Tyrosine Kinase receptor activation [19].

3.5. SOS1 and AhR are critical for dioxin-dependent changes in growth. Since the Ras-ERK pathway in implicated in cell growth, we tested the effect of TCDD treatment on HepG2 cells proliferation. As shown in figure $6 \mathrm{~A} \& 6 \mathrm{~B}$, TCDD elicited a statistically significant $20 \%$ increase in cellular growth in the absence or in the presence of a control siRNA. Following the knock down of SOS1 gene expression (Fig 6A) using two specific siRNAs, the effect of TCDD was completely abolished. A partial decrease in basal cellular proliferation was also noted, which is not surprising given the implication of the SOS1-RasERK pathway in cellular proliferation. In addition, AhR-specific siRNAs also prevented the TCDD effects (Fig 6B). We conclude that SOS1 induction plays a critical role in the TCDDelicited increase in cellular proliferation. 


\section{Discussion}

AhR activation by polyaromatic and polyhalogenated hydrocarbons has traditionally been associated with induced expression of phase I and phase II xenobiotic metabolizing enzymes, which promote the clearance of pollutants and drugs from metazoan organisms [20]. However, recent toxicogenomic studies, as well as knock-out studies in mice, have unveiled new AhR target genes [13, 21-23] and suggested novel functions for this receptor including the regulation of cell proliferation and migration. Several large-scale studies in HepG2 cells $[21,22,24]$ indicated that the SOS1 gene could be a target of TCDD. SOS1, a Guanine Exchange Factor, is essential for the activation of the Ras and Rac signaling pathways, which lead to the regulation of some of the most important cellular functions including cell division, differentiation and migration [4]. Despite these critical roles, neither the regulation of SOS1 expression nor the characterization of its gene promoter has been carried out previously. We recently observed that AhR ligands increase HepG2 cell proliferation and hypothesized that increased SOS1 expression might be involved in this biological effect. We first validated our transcriptomic experiments and showed that the AhR and its ligands positively regulate SOS1 gene expression. Then, we characterized and subcloned, for the first time to our knowledge, the human SOS1 gene promoter. We showed that TCDD and other AhR ligands regulate, via transcriptional mechanisms their activities upon AhR activation followed by direct promoter binding of AhR to XRE sites. Interestingly, the level of induction of SOS1 elicited by each ligand is different. This is in line with one of our former studies showing that the transcriptional response of the $\mathrm{AhR}$ depends on the nature of its ligand ([25]) and, more generally, with the SAhRM concept [26]. Finally, we focused on the implications of the regulation of SOS1 expression by environmental pollutants. Using a siRNA strategy, we demonstrated that increased SOS1 expression is directly linked to Ras and ERK activation, which promotes cell division. This study demonstrates that the activation of the Ras-ERK pathway could be achieved by increasing the amount of the SOS1 protein. These results suggest that, under our cell culture conditions, the amount of SOS1 protein is limiting.

The activation of the Ras ERK pathway has been studied extensively in the past and several mechanisms have been reported and characterized [19]. Receptor activation followed by SOS1 recruitment is a classical mechanism under physiological and certain pathological conditions and is one paradigm for cellular signaling [6]. In cancer cells, considerable research has been devoted to the upregulation of this pathway through activating Ras 
mutations. Similarly, the function of SOS1 has been considerably investigated [27-29]. Recent studies also have correlated SOS1 activating mutations to several diseases of development including Noonan syndrome, a developmental disorder characterized by short stature, facial dysmorphia, congenital heart defects and skeletal abnormalities $[7,8,30]$ as well as hereditary gingival fibromatosis type 1 , a benign overgrowth condition of the gingiva [31]. Despite considerable attention to these gains of function mutations, SOS1 gene regulation has remained poorly characterized [32,33]. We speculate that the findings reported here on the upregulation of SOS1 gene expression by environmental pollutants might constitute one mechanism, which accounts for TCDD and other AhR ligand-mediated carcinogenesis. We expect this effect to be particularly relevant in cancerous cells, which do not exhibit Ras mutations. Indeed, continuous upregulation of SOS1 in these cells may mimic Ras mutational activation and lead to the permanent stimulation of the downstream signaling pathway, which controls cellular proliferation. Thus, our data imply that increased SOS1 expression may constitute an alternative to the activating mutations of Ras and that it should be relevant to explore and characterize alterations of the expression of this gene in cancer cells [34-36]. Furthermore, it is unclear at this stage whether these two mechanisms can be additive or not. An important question, in this respect, is whether gene induction-mediated chronic activation of the SOS1/Ras pathway can be achieved readily in humans. Because of the high contamination levels and widespread distribution of AhR ligands in our environment, chronic exposure to such pollutants is very common, especially in industrialized countries. In addition, long term effects could also be triggered by acute high level exposure to these toxins. Indeed, pollutants such as dioxins tend to resist metabolism and accumulate in human and animal adipose tissue, leading to a permanent internal exposure [37].

Genetic and developmental studies in flies and mice have suggested different and unexpected connections between the AhR and the small G proteins network. A recent study by CarvajalGonzalez JM et al using AhR KO mice models, has unveiled a link between the receptor and the Vav3, a guanosine diphosphate/guanosine triphosphate exchange factor for Rho/Rac GTPases [38]. Moreover, Son of Sevenless (SOS) has been shown to be a major player in the development of Drosophila eye ommatidia. SOS mutations change ommatidia organization and the color perception of the fly $[39,40]$. Spineless, the Drosophila AhR ortholog, is involved in the ommatidal mosaic formation as well as SOS1 [41]. Thus, these two genes converge in the control of eye development. It is tempting to speculate that this genetic interaction may be related to a possible conservation of the control of SOS gene expression by 
spineless in this invertebrate species. Interestingly, invertebrate AhR orthologs (Spineless and AHR-1 from Caenorhabditis elegans) display structural and functional similarities with vertebrate AhR such as transcription factor activity and XRE binding. However, they do not bind dioxins or other hydrocarbon ligands and, at this stage, their possible receptor functions and their activation mechanisms have not been characterized. It is intriguing to consider that, while Spineless and AHR-1 are implicated in fundamental developmental processes, recent in vivo and in vitro evidences have established direct connections between the mammalian AhR and developmentally relevant pathways such as cellular proliferation, cellular migration and epithelial mesenchymal transition [42,43]. Thus, it is likely that several of those AhR functions including SOS1 regulation, have been conserved through evolution and the present study as well as several others suggest that one mechanism of pollutants toxicity would be to disrupt such basic developmental functions of this receptor.

5. Acknowledgements: This work was supported by AFSSET (Agence Française de Sécurité Sanitaire de l'Environnement et du Travail; all authors); the ANR (Agence Nationale de la Recherche, 06SEST26, Oncopop; all authors); ARC (Association pour la Recherche sur le Cancer, 3927; all authors); the CNRS (Centre Nationale de la recherche scientifique Martine Aggerbeck); the Fondation pour la Recherche Médicale (Bourse post-doctorale, Linh-Chi Bui); INSERM (Institut National de la Santé et de la Recherche Médicale; all authors); the Ligue contre le Cancer (Bourse post-doctorale, Linh-Chi Bui); the Ministère de l'enseignement supérieur et de la recherche (Bourse doctorale, Aline Chevallier, Ariane Ambolet-Camoit); the Région Ile de France (bourse doctorale, Stéphane Pierre); the Université Paris Descartes. We thank Dr Lawrence Aggerbeck for his critical reading of this manuscript. 


\section{Legends for figures}

Figure 1: SOS1 is a target of TCDD in human hepatocarcinoma HepG2 cells. (A) Quantitative real-time PCR (A, C) and western blot analysis (B, D) of SOS1 mRNA and protein levels as a function of TCDD concentration (0-100 nM, 48h) (A, B) and as a function of time (0-48h, $25 \mathrm{nM}$ TCDD) (C, D) in human hepatocarcinoma HepG2 cells. Relative mRNA levels were calculated using controls values $(0 \mathrm{nM}$ for $\mathrm{A}$ or $0 \mathrm{~h}$ for $\mathrm{C})$ as references. Actin was used as a loading control for western blots. ${ }^{* *}, \mathrm{p}<0.01$ as compared to non-treated controls $(n>3)$.

Figure 2: Involvement of the AhR in the regulation of SOS1 mRNA and protein expression in HepG2 cells. (A) SOS1 mRNA levels measured by quantitative real-time PCR after 48h-treatment of HepG2 cells with various AhR ligands (TCDD, $25 \mathrm{nM}$; Benzo(a)pyrene or BaP, $5 \mu \mathrm{M}$; Quercetin, $25 \mu \mathrm{M}$ ). Relative mRNA levels were calculated using control value as reference (B) AhR mRNA levels measured by quantitative real-time PCR in AhR (siAhR) or control (siC) siRNA-transfected HepG2 cells (NT: non-treated; TCDD: TCDD-treated). (C) SOS1 mRNA levels measured by quantitative real-time PCR in AhR (siAhR) or control ( $\mathrm{siC}$ ) siRNA-transfected HepG2 cells (NT: non-treated; TCDD: TCDD-treated). (A, B, C: ***, p < 0.001; **, p < 0.01 and $*, p<0.05$ compared to controls $(n>3))$. (D) Western blot analysis and relative quantification of SOS1 and AhR protein levels in AhR (siAhR) or Control (siC) siRNA-transfected HepG2 cells upon TCDD (+) treatment. Actin was used as a loading control for western blots $(n=3)$.

Figure 3: The AhR dependent-SOS1 regulation is transcriptional. (A) SOS1 mRNA levels measured by relative quantitative real-time PCR in the presence of DRB, an inhibitor of RNA polymerase II in non-treated $(\mathrm{NT}+\mathrm{DRB})$ and TCDD-treated $(\mathrm{T}+\mathrm{DRB}) \mathrm{HepG} 2$ cells. Cells were treated or not with $25 \mathrm{nM}$ TCDD for $16 \mathrm{~h}$ then with DRB and subsequently harvested (between 0 and 12h). We use a semi-logarithmic representation. (B) Diagram of the SOS1 promoter $(-2200 /+37)$ using the translation start site as reference $(+1)$. Localizations of both XRE consensus sites (-940 and -2060 bp) and oligonucleotides used for primer extension assay, ChIP and EMSA are indicated as well as the promoter section used for the reported gene (luciferase) experiments (see below). 
Figure 4: SOS1 regulation depends on the binding of the AhR to SOS1 promoter. (A) Diagram of the SOS1 promoter subcloned in the Gaussia luciferase basic vector (with both XRE consensus sites at -940 and $-2060 \mathrm{bp}$ ) and activity of the SOS1 promoter measured after transfection of HepG2 cells with a vector (pGLuc-SOS1) containing the $-2200 /+37$ theoretical promoter region of SOS1 upstream from the Gaussia luciferase reporter gene $(+1$ refers to the translation start site). The cells were treated (+) or not (-) with TCDD. The medium was sampled after 0, 6, 24 and 48 hours. An empty vector (pGLuc) was used as a control. Relative luciferase activities are reported on the y-axis and are calculated using non-treated conditions (-) as control reference for both vectors (B) Activity of the SOS1 promoter measured after transfection of HepG2 cells with a control ( $\mathrm{siC}$ ) or AhR targeting (siAhR) siRNA and the vector containing the $-2200 /+37$ theoretical promoter region of SOS1 upstream from the Gaussia luciferase reporter gene (pGLuc-SOS1). The cells were treated (+) or not (-) with TCDD for $48 \mathrm{~h}$. The medium was sampled after 48 hours. An empty vector (pGLuc) was used as a control. Relative luciferase units (RLU) are reported on the y-axis (C) Electrophoretic Mobility Shift Assay (EMSA) using a specific labeled double strand probe encompassing the first XRE site in the SOS1 gene promoter (-940, see figure 3 and 4A), nuclear HepG2 extracts (cells were treated or not with $25 \mathrm{nM}$ TCDD for $75 \mathrm{mins}$ ), an unlabelled competitive oligonucleotide (compet. XRE1 SOS1 with the same sequence than the probe, 10X and 20X) an AhR antibody (anti-AhR, 3 and $6 \mu \mathrm{g}$ ) and an unlabelled competitive oligonucleotide (compet. XRE1 SOS1 with a mutated sequence 20X) (D) Chromatin Immunoprecipitation (ChIP) performed with a mock or a specific AhR antibody (15 or 45 minutes of TCDD treatment of HepG2 cells, respectively T15 or T45). Specific primers surrounding the proximal XRE (-940, see figure 3 and 4A) of the Sos1 gene promoter were used for the study. Input refers to non-precipitated samples and is used to ensure proper "loading" controls before precipitation. The mock antibody is used to measure unspecific precipitations. Fold induction refers to relative levels calculated using non-treated (NT) conditions as reference. ***, $\mathrm{p}<0.001$ and $*, \mathrm{p}<0.05$ as compared to controls $(\mathrm{n}=3)$.

\section{Figure 5: Increased expression of SOS1 after TCDD treatment stimulates Ras activity} and ERK1/2 phosphorylation (A) Western blot analysis of Ras-GTP protein levels after a Ras-GTP specific pull down assay in untreated (-) or $25 \mathrm{nM}$ TCDD-treated (+) HepG2 cells upon $48 \mathrm{~h}$ treatment. Input Ras levels show the levels of Ras before precipitation. Precipitation is undertaken using a protein, which specifically interacts with Ras-GTP (Raf), linked to GST-beads. Negative (Ctrl -) and positive $(\mathrm{Ctrl}+)$ control respectively refers to extracts over- 
treated with GDP or GTP-YS before precipitation (see Material and methods for more details) (B) Western blot analysis of phosphorylated ERK levels (ERK-P) in untreated (NT) or TCDD-treated (T) HepG2 cells. Total ERK was used as a loading control. The quantification of three independent experiments is presented in the right panel. Fold induction refers to relative levels calculated using the NT condition as reference. *,p $<0.05$ compared to controls $(n=3)$. (C) Western blot analysis of Ras-GTP and SOS1 protein levels after Ras-GTP specific pull down assays of untreated (-, NT) or $25 \mathrm{nM}$ TCDD-treated (+, T) HepG2 cells extracts after SOS1 (siSOS1) or control siRNA (siC) transfection. The quantification of three independent experiments is presented in the right panel for both SOS1 and Ras-GTP proteins. Fold induction refers to relative levels calculated using NT conditions as reference. $* * *, p<$ 0.001 and $* *, \mathrm{p}<0.01$ compared to controls $(\mathrm{n}=3)$.

Figure 6: TCDD-stimulated HepG2 cell growth depends on both AhR expression and increased expression of SOS1. (A) HepG2 cells were either not transfected (wo si RNA) or transfected with control siRNA (siC) or SOS1 siRNA (siSOS1). One day after, they were treated (T) or not (NT) with $25 \mathrm{nM}$ TCDD for $24 \mathrm{~h}$. Cell numbers, expressed in AU (Arbitrary Unit), were quantified for each condition. In the right panel of the figure, a western blotanalysis of SOS1 protein levels is presented. (B) HepG2 cells were either not transfected (wo si RNA) or transfected with siControl (siC) or siAhR (siAhR). They were treated (T) or not (NT) with $25 \mathrm{nM}$ TCDD for $48 \mathrm{~h}$. Cell numbers, expressed in AU (Arbitrary Unit), were quantified for each condition. In the right panel of the figure, a western blot-analysis of AhR protein levels is presented $*, p<0.05$ compared to controls $(n=3)$. 


\section{Conflict of interest statement}

All authors disclose any actual or potential conflict of interest including any financial, personal or other relationships with other people or organizations within three (3) years of beginning the work submitted. 


\section{References}

[1] Karnoub AE, Weinberg RA. Ras oncogenes: split personalities. Nat Rev Mol Cell Biol 2008;9:517-31.

[2] Gibbs JB, Sigal IS, Poe M, Scolnick EM. Intrinsic GTPase activity distinguishes normal and oncogenic ras p21 molecules. Proc Natl Acad Sci U S A 1984;81:5704-8.

[3] Shimizu K, Goldfarb M, Suard Y, Perucho M, Li Y, Kamata T, et al. Three human transforming genes are related to the viral ras oncogenes. Proc Natl Acad Sci U S A 1983;80:2112-6.

[4] Innocenti M, Tenca P, Frittoli E, Faretta M, Tocchetti A, Di Fiore PP, et al. Mechanisms through which Sos-1 coordinates the activation of Ras and Rac. J Cell Biol 2002;156:125-36.

[5] McKay MM, Morrison DK. Integrating signals from RTKs to ERK/MAPK. Oncogene 2007;26:3113-21.

[6] Nimnual A, Bar-Sagi D. The two hats of SOS. Sci STKE 2002;2002:pe36.

[7] Roberts AE, Araki T, Swanson KD, Montgomery KT, Schiripo TA, Joshi VA, et al. Germline gain-of-function mutations in SOS1 cause Noonan syndrome. Nat Genet 2007;39:70-4.

[8] Tartaglia M, Pennacchio LA, Zhao C, Yadav KK, Fodale V, Sarkozy A, et al. Gain-of-function SOS1 mutations cause a distinctive form of Noonan syndrome. Nat Genet 2007;39:75-9.

[9] Steenland K, Bertazzi P, Baccarelli A, Kogevinas M. Dioxin revisited: developments since the 1997 IARC classification of dioxin as a human carcinogen. Environ Health Perspect 2004;112:1265-8.

[10] Okey AB. An aryl hydrocarbon receptor odyssey to the shores of toxicology: the Deichmann Lecture, International Congress of Toxicology-XI. Toxicol Sci 2007;98:5-38.

[11] Fukunaga BN, Probst MR, Reisz-Porszasz S, Hankinson O. Identification of functional domains of the aryl hydrocarbon receptor. $J$ Biol Chem 1995;270:29270-8.

[12] Rowlands JC, Gustafsson JA. Aryl hydrocarbon receptor-mediated signal transduction. Crit Rev Toxicol 1997;27:109-34. 
[13] Weiss C, Faust D, Durk H, Kolluri SK, Pelzer A, Schneider S, et al. TCDD induces c-jun expression via a novel Ah (dioxin) receptor-mediated p38-MAPKdependent pathway. Oncogene 2005;24:4975-83.

[14] Connor KT, Aylward LL. Human response to dioxin: aryl hydrocarbon receptor (AhR) molecular structure, function, and dose-response data for enzyme induction indicate an impaired human AhR. J Toxicol Environ Health B Crit Rev 2006;9:147-71.

[15] Fernandez-Salguero PM, Ward JM, Sundberg JP, Gonzalez FJ. Lesions of arylhydrocarbon receptor-deficient mice. Vet Pathol 1997;34:605-14.

[16] Gonzalez FJ, Fernandez-Salguero P. The aryl hydrocarbon receptor: studies using the AHR-null mice. Drug Metab Dispos 1998;26:1194-8.

[17] Bui LC, Tomkiewicz C, Chevallier A, Pierre S, Bats AS, Mota S, et al. Nedd9/Hef1/Cas-L mediates the effects of environmental pollutants on cell migration and plasticity. Oncogene 2009.

[18] Puga A, Maier A, Medvedovic M. The transcriptional signature of dioxin in human hepatoma HepG2 cells. Biochem Pharmacol 2000;60:1129-42.

[19] Ramos JW. The regulation of extracellular signal-regulated kinase (ERK) in mammalian cells. Int J Biochem Cell Biol 2008;40:2707-19.

[20] Schwanekamp JA, Sartor MA, Karyala S, Halbleib D, Medvedovic M, Tomlinson CR. Genome-wide analyses show that nuclear and cytoplasmic RNA levels are differentially affected by dioxin. Biochim Biophys Acta 2006;1759:388-402.

[21] Frueh FW, Hayashibara KC, Brown PO, Whitlock JP, Jr. Use of cDNA microarrays to analyze dioxin-induced changes in human liver gene expression. Toxicol Lett 2001;122:189-203.

[22] Marchand A, Tomkiewicz C, Marchandeau JP, Boitier E, Barouki R, Garlatti M. 2,3,7,8-Tetrachlorodibenzo-p-dioxin induces insulin-like growth factor binding protein-1 gene expression and counteracts the negative effect of insulin. Mol Pharmacol 2005;67:444-52.

[23] Gomez-Duran A, Carvajal-Gonzalez JM, Mulero-Navarro S, Santiago-Josefat B, Puga A, Fernandez-Salguero PM. Fitting a xenobiotic receptor into cell homeostasis: how the dioxin receptor interacts with TGFbeta signaling. Biochem Pharmacol 2009;77:700-12.

[24] Park R, Kim DH, Kim MS, So HS, Chung HT, Kwon KB, et al. Association of Shc, Cbl, Grb2, and Sos following treatment with 2,3,7,8-tetrachlorodibenzo-p- 
dioxin in primary rat hepatocytes. Biochem Biophys Res Commun 1998;253:57781.

[25] Gouedard C, Barouki R, Morel Y. Dietary polyphenols increase paraoxonase 1 gene expression by an aryl hydrocarbon receptor-dependent mechanism. Mol Cell Biol 2004;24:5209-22.

[26] Safe S. 3-methylcholanthrene induces differential recruitment of aryl hydrocarbon receptor to human promoters. Toxicol Sci 2010;117:1-3.

[27] Margarit SM, Sondermann H, Hall BE, Nagar B, Hoelz A, Pirruccello M, et al. Structural evidence for feedback activation by Ras.GTP of the Ras-specific nucleotide exchange factor SOS. Cell 2003;112:685-95.

[28] Sondermann H, Soisson SM, Boykevisch S, Yang SS, Bar-Sagi D, Kuriyan J. Structural analysis of autoinhibition in the Ras activator Son of sevenless. Cell 2004;119:393-405.

[29] Zarich N, Oliva JL, Martinez N, Jorge R, Ballester A, Gutierrez-Eisman S, et al. Grb2 is a negative modulator of the intrinsic Ras-GEF activity of hSos1. Mol Biol Cell 2006;17:3591-7.

[30] Narumi Y, Aoki Y, Niihori T, Sakurai M, Cave H, Verloes A, et al. Clinical manifestations in patients with SOS1 mutations range from Noonan syndrome to CFC syndrome. J Hum Genet 2008;53:834-41.

[31] DeAngelo S, Murphy J, Claman L, Kalmar J, Leblebicioglu B. Hereditary gingival fibromatosis--a review. Compend Contin Educ Dent 2007;28:138-43; quiz 44, 52.

[32] Findlay GM, Pawson T. How is SOS activated? Let us count the ways. Nat Struct Mol Biol 2008;15:538-40.

[33] Quilliam LA. New insights into the mechanisms of SOS activation. Sci STKE 2007;2007:pe67.

[34] Watanabe T, Shinohara N, Moriya K, Sazawa A, Kobayashi Y, Ogiso Y, et al. Significance of the Grb2 and son of sevenless (Sos) proteins in human bladder cancer cell lines. IUBMB Life 2000;49:317-20.

[35] Koizumi F, Shimoyama T, Taguchi F, Saijo N, Nishio K. Establishment of a human non-small cell lung cancer cell line resistant to gefitinib. Int $\mathbf{J}$ Cancer 2005;116:36-44. 
[36] Feller SM, Tuchscherer G, Voss J. High affinity molecules disrupting GRB2 protein complexes as a therapeutic strategy for chronic myelogenous leukaemia. Leuk Lymphoma 2003;44:411-27.

[37] Baccarelli A, Pesatori AC, Masten SA, Patterson DG, Jr., Needham LL, Mocarelli P, et al. Aryl-hydrocarbon receptor-dependent pathway and toxic effects of TCDD in humans: a population-based study in Seveso, Italy. Toxicol Lett 2004;149:287-93.

[38] Carvajal-Gonzalez JM, Mulero-Navarro S, Roman AC, Sauzeau V, Merino JM, Bustelo XR, et al. The dioxin receptor regulates the constitutive expression of the vav3 proto-oncogene and modulates cell shape and adhesion. Mol Biol Cell 2009;20:1715-27.

[39] Rogge RD, Karlovich CA, Banerjee U. Genetic dissection of a neurodevelopmental pathway: Son of sevenless functions downstream of the sevenless and EGF receptor tyrosine kinases. Cell 1991;64:39-48.

[40] Bonfini L, Karlovich CA, Dasgupta C, Banerjee U. The Son of sevenless gene product: a putative activator of Ras. Science 1992;255:603-6.

[41] Wernet MF, Mazzoni EO, Celik A, Duncan DM, Duncan I, Desplan C. Stochastic spineless expression creates the retinal mosaic for colour vision. Nature 2006;440:174-80.

[42] Barouki R, Coumoul X, Fernandez-Salguero PM. The aryl hydrocarbon receptor, more than a xenobiotic-interacting protein. FEBS Lett 2007;581:360815.

[43] Diry M, Tomkiewicz C, Koehle C, Coumoul X, Bock KW, Barouki R, et al. Activation of the dioxin/aryl hydrocarbon receptor (AhR) modulates cell plasticity through a JNK-dependent mechanism. Oncogene 2006. 


\section{Figure 1}

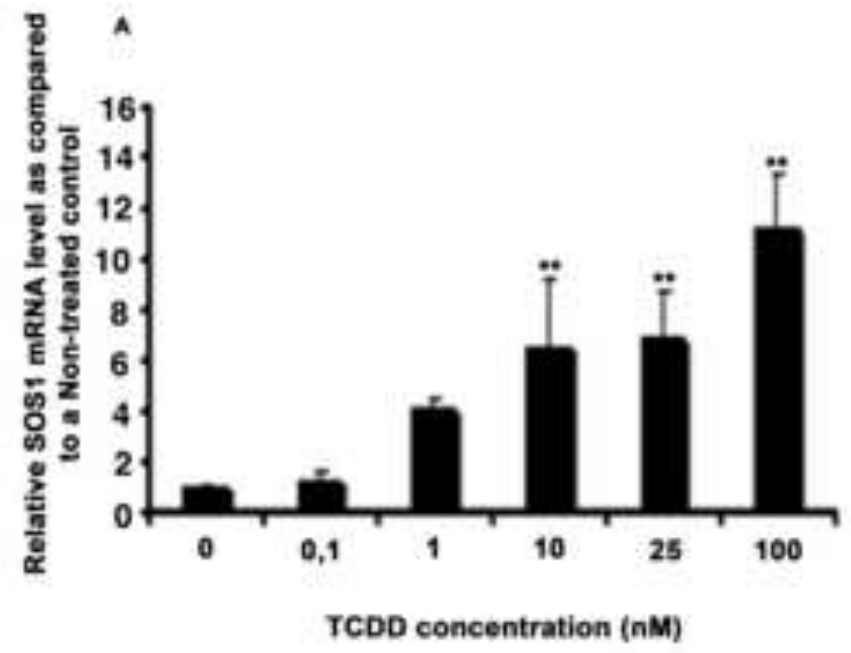

B

$\begin{array}{lllllll}0 & 0.1 & 1 & 10 & 25 & 100 & \text { TCOD (nM) }\end{array}$

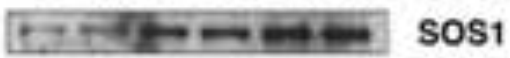

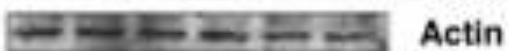

o

$\begin{array}{lllllll}0 & 4 & 8 & 16 & 24 & 48 & \text { Time (h) }\end{array}$

rement sosi

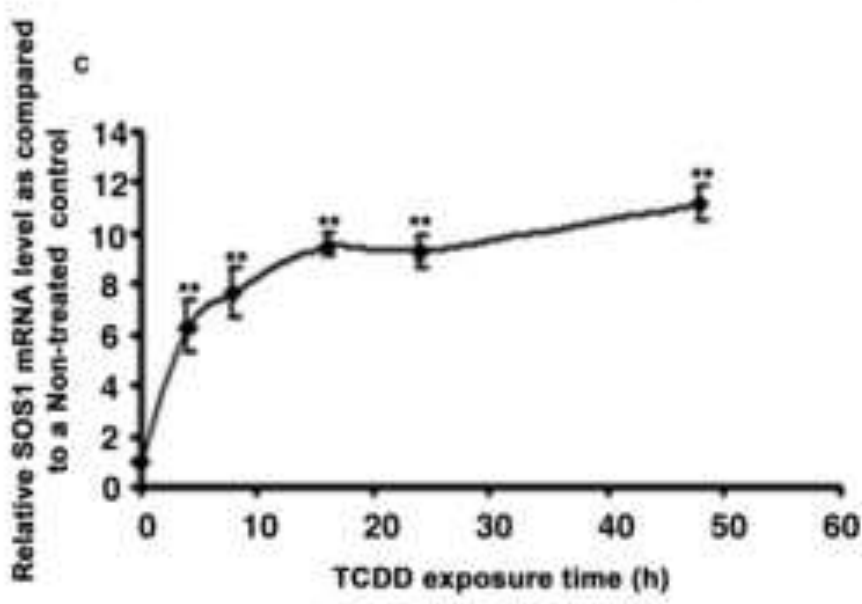

Actin 


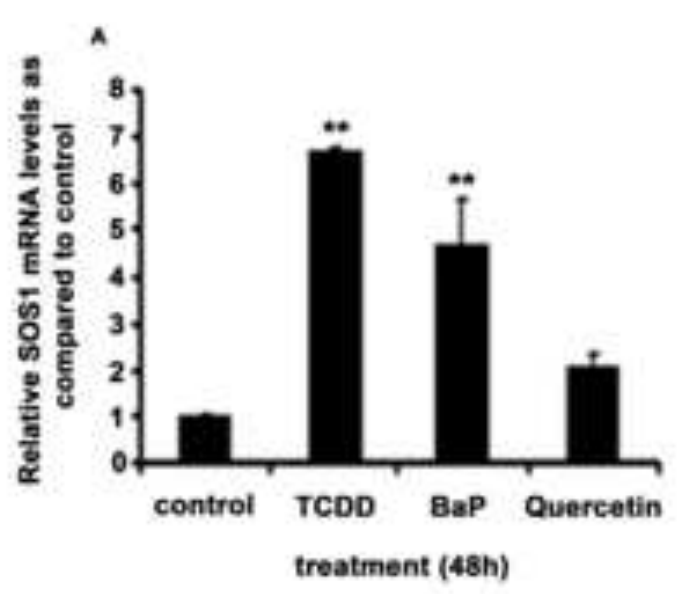

Figure 2
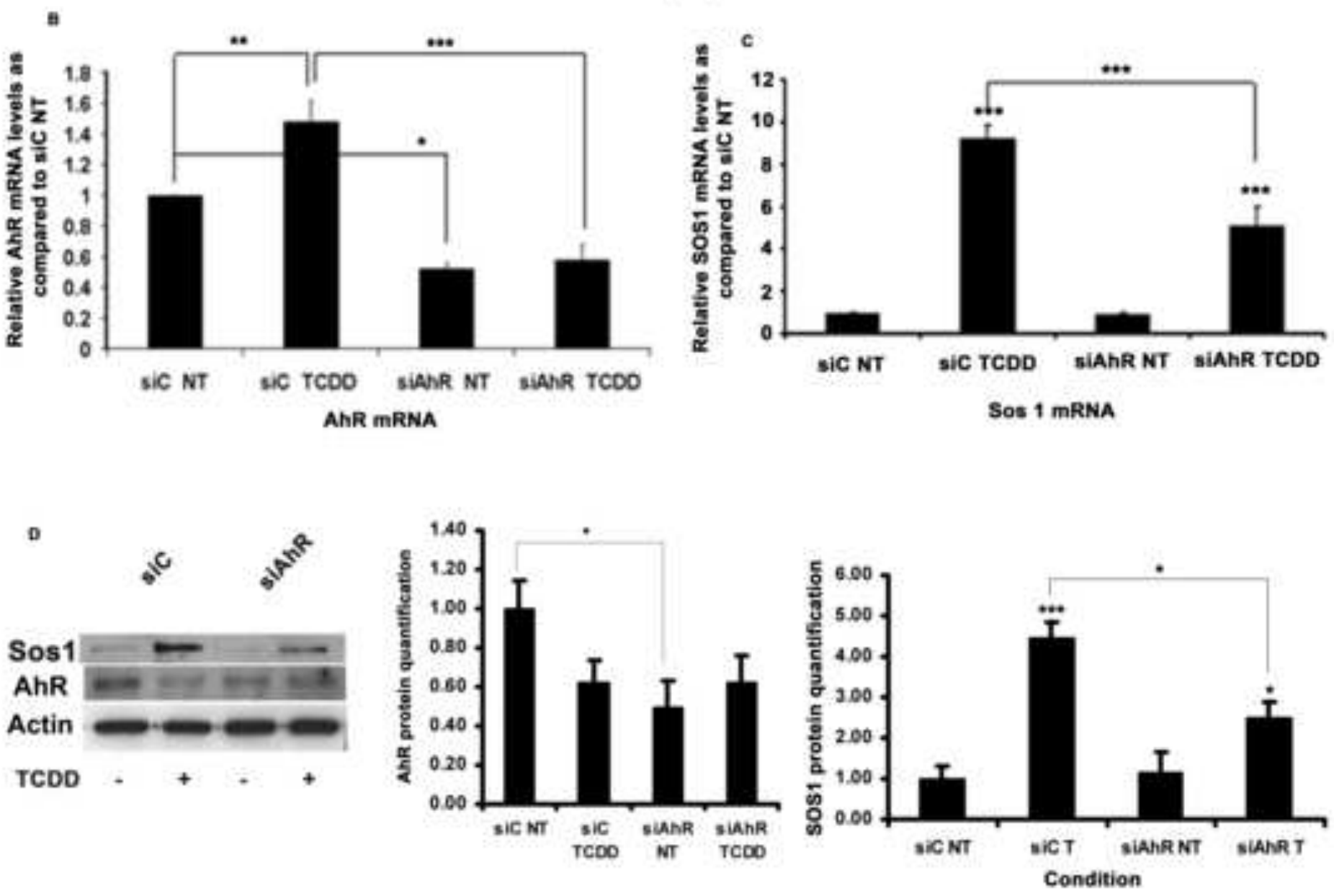


\section{Figure 3}

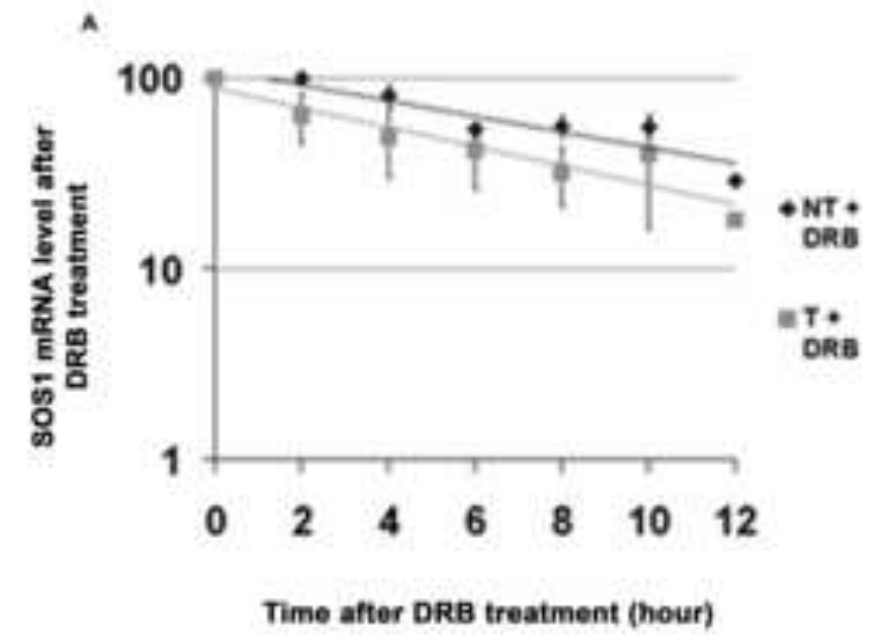

n

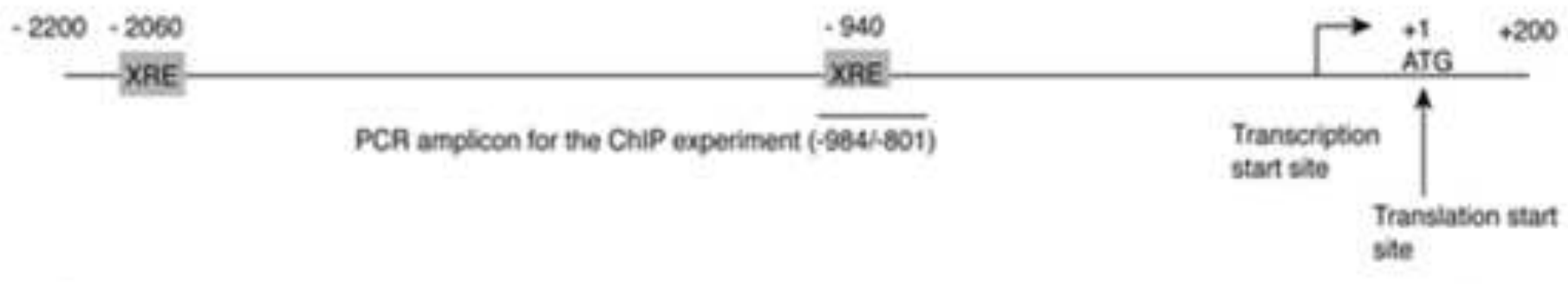

Promoter section used for the reporter gene (lucterase) studies $(-2200 /+37)$ 


\section{Figure 4}

$\wedge$

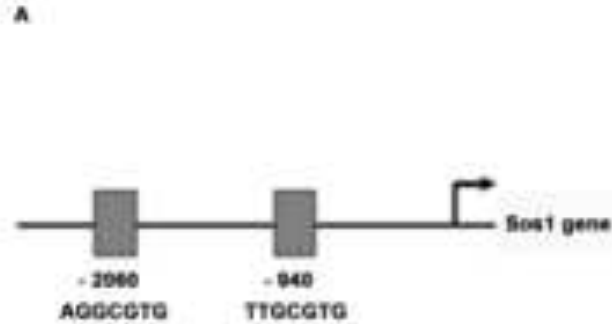

a

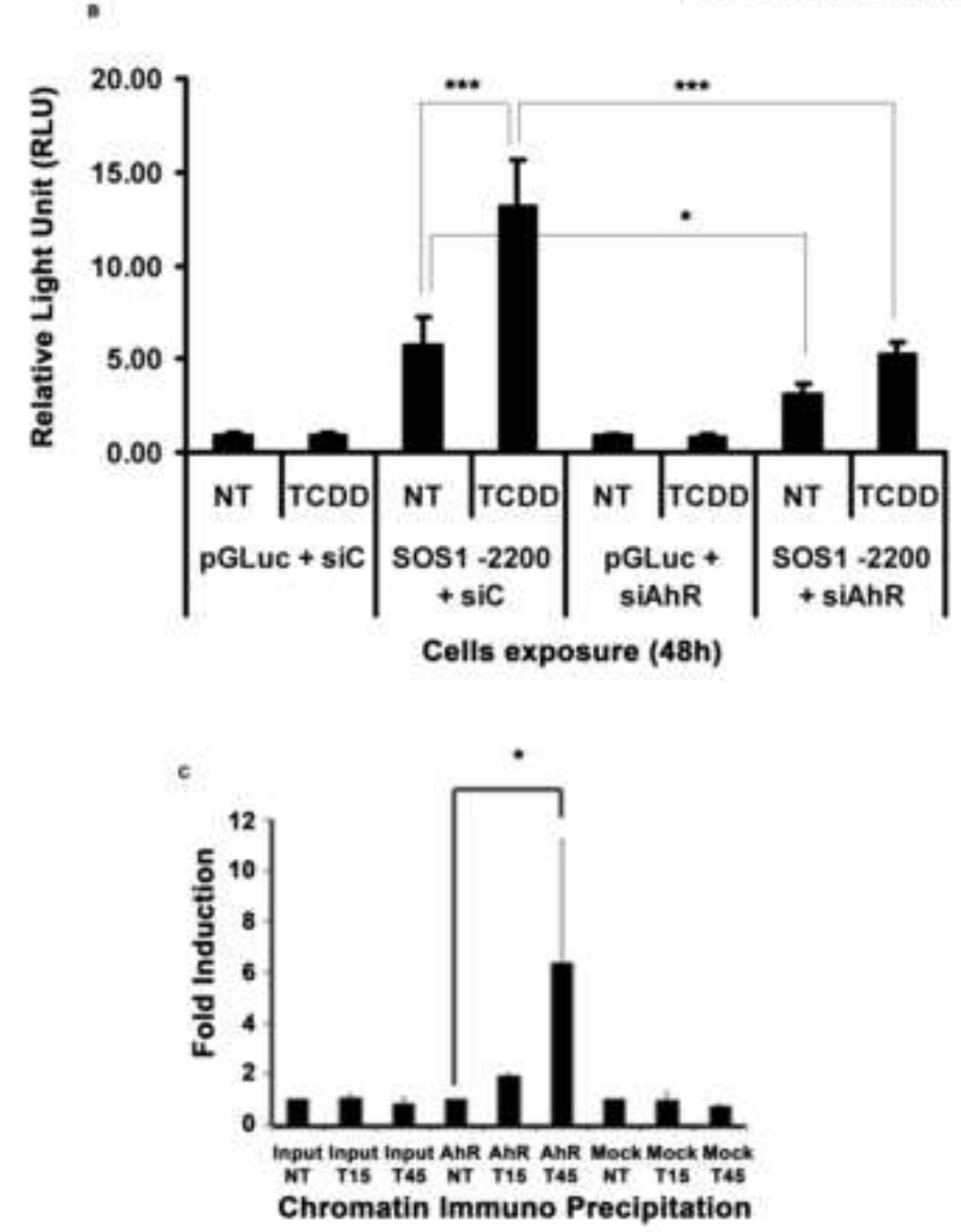

Cells exposure (48h)

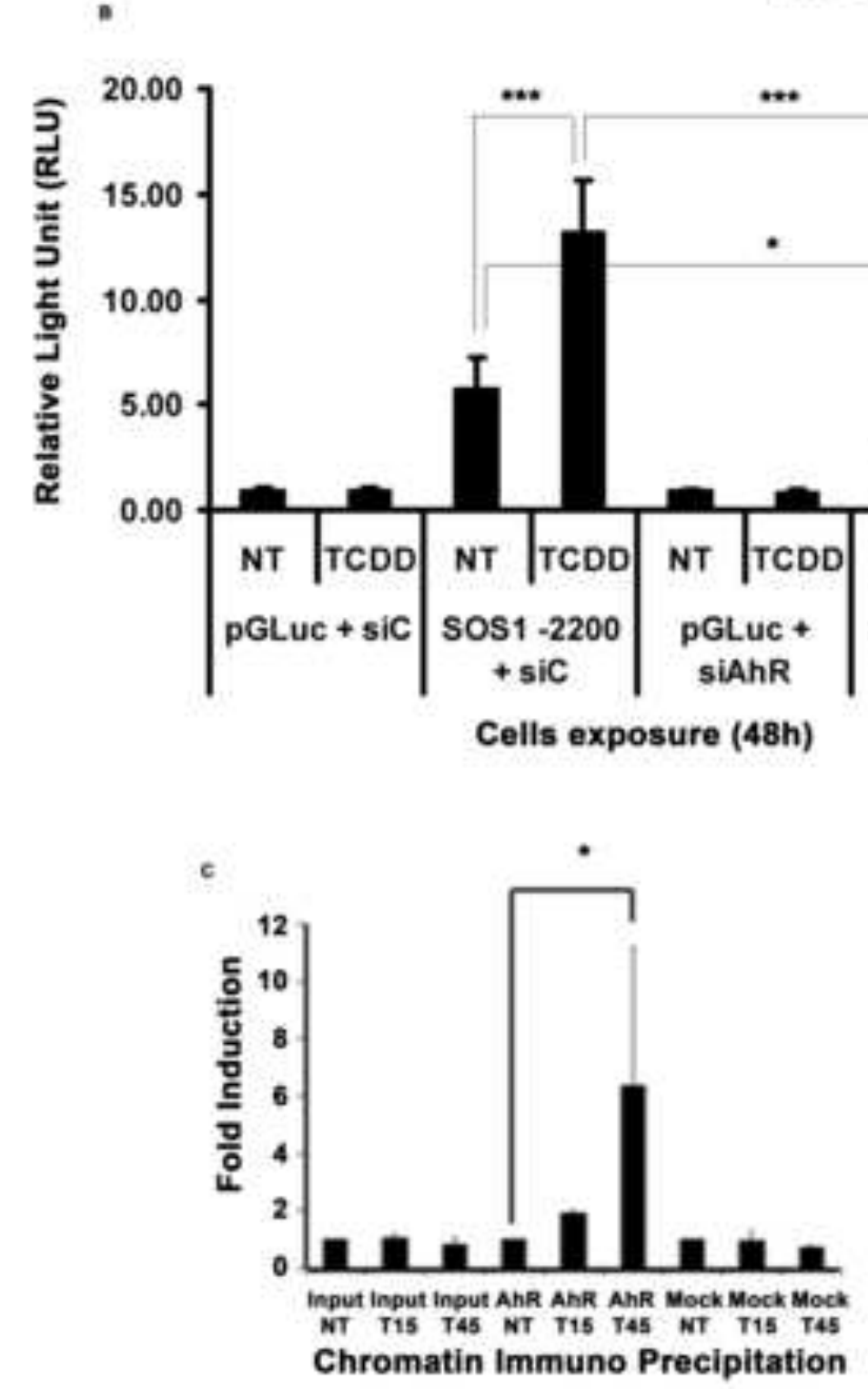

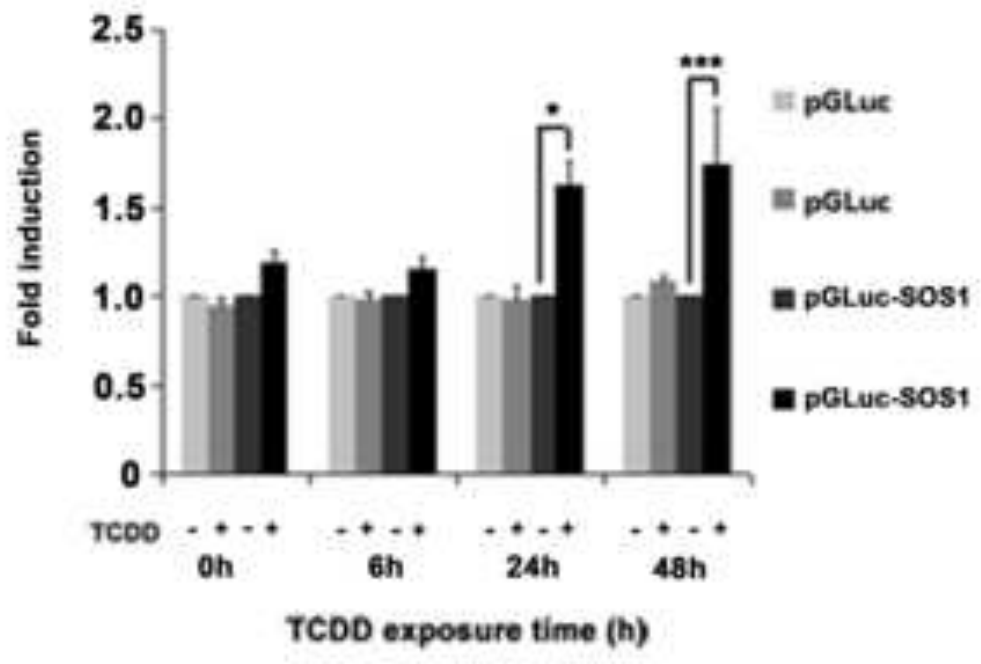




\section{Figure 5}

A

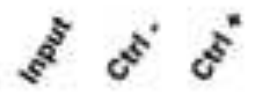

\section{Ras-GTP}

TCOD (25nM)

B

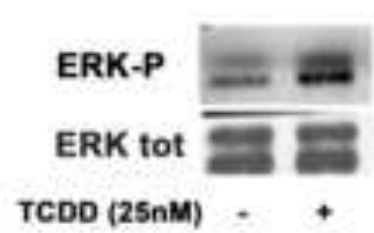

c

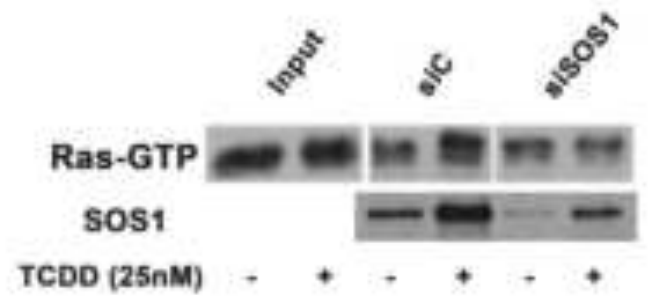

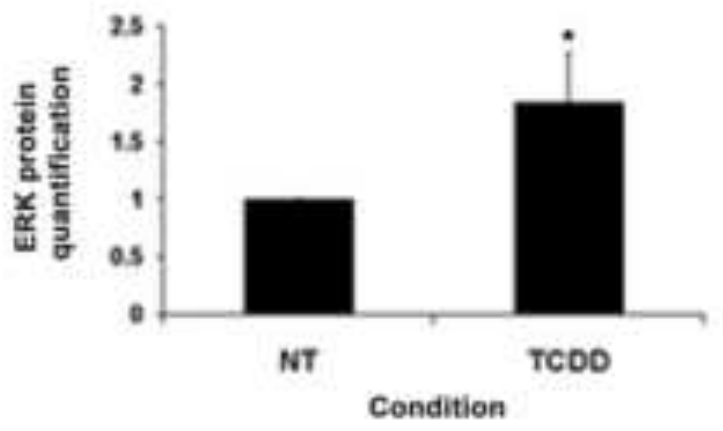
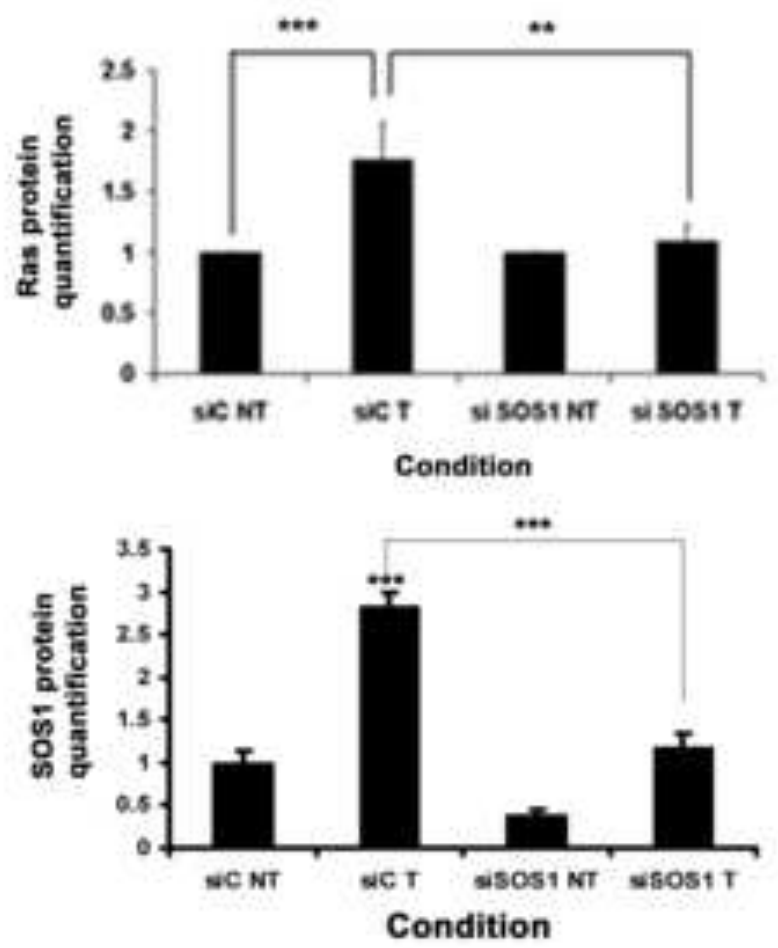


\section{Figure 6}

A

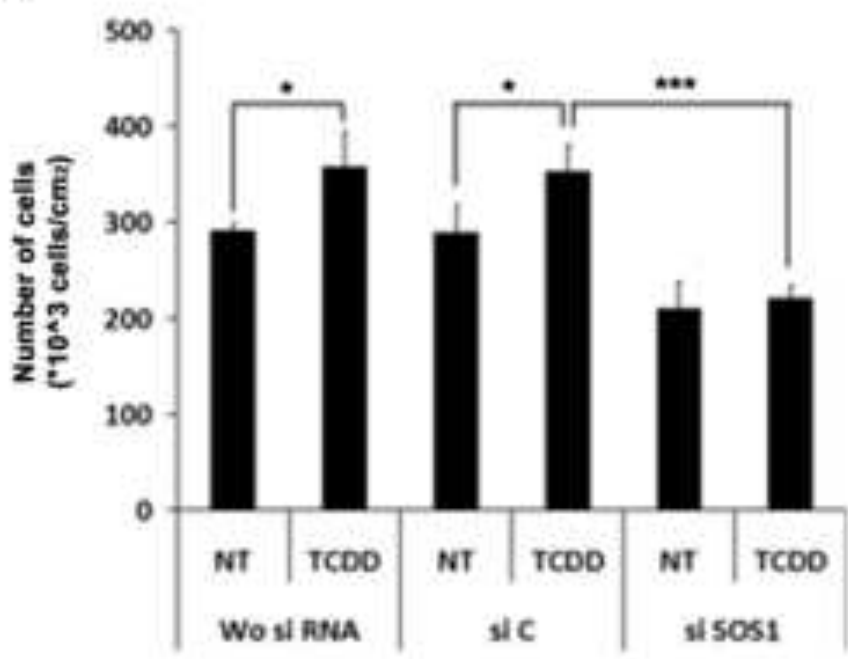

Treatment

B
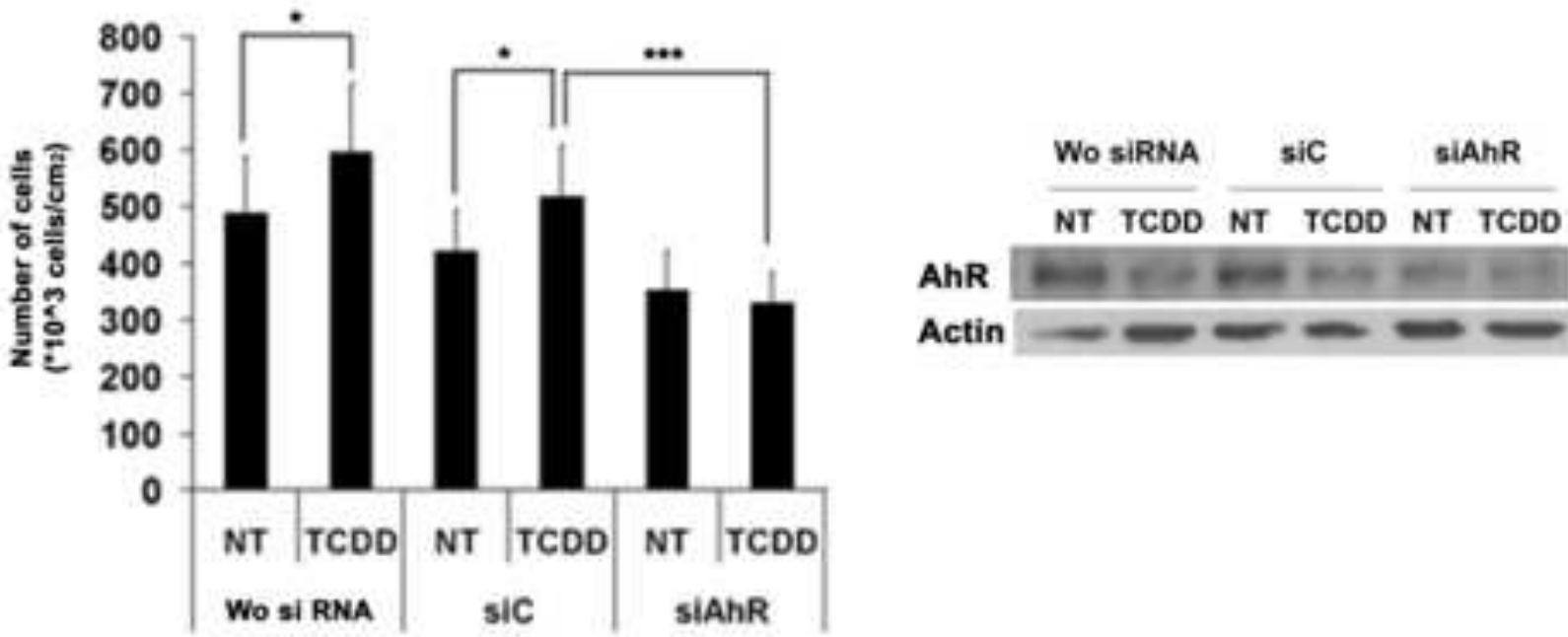

Treatment 


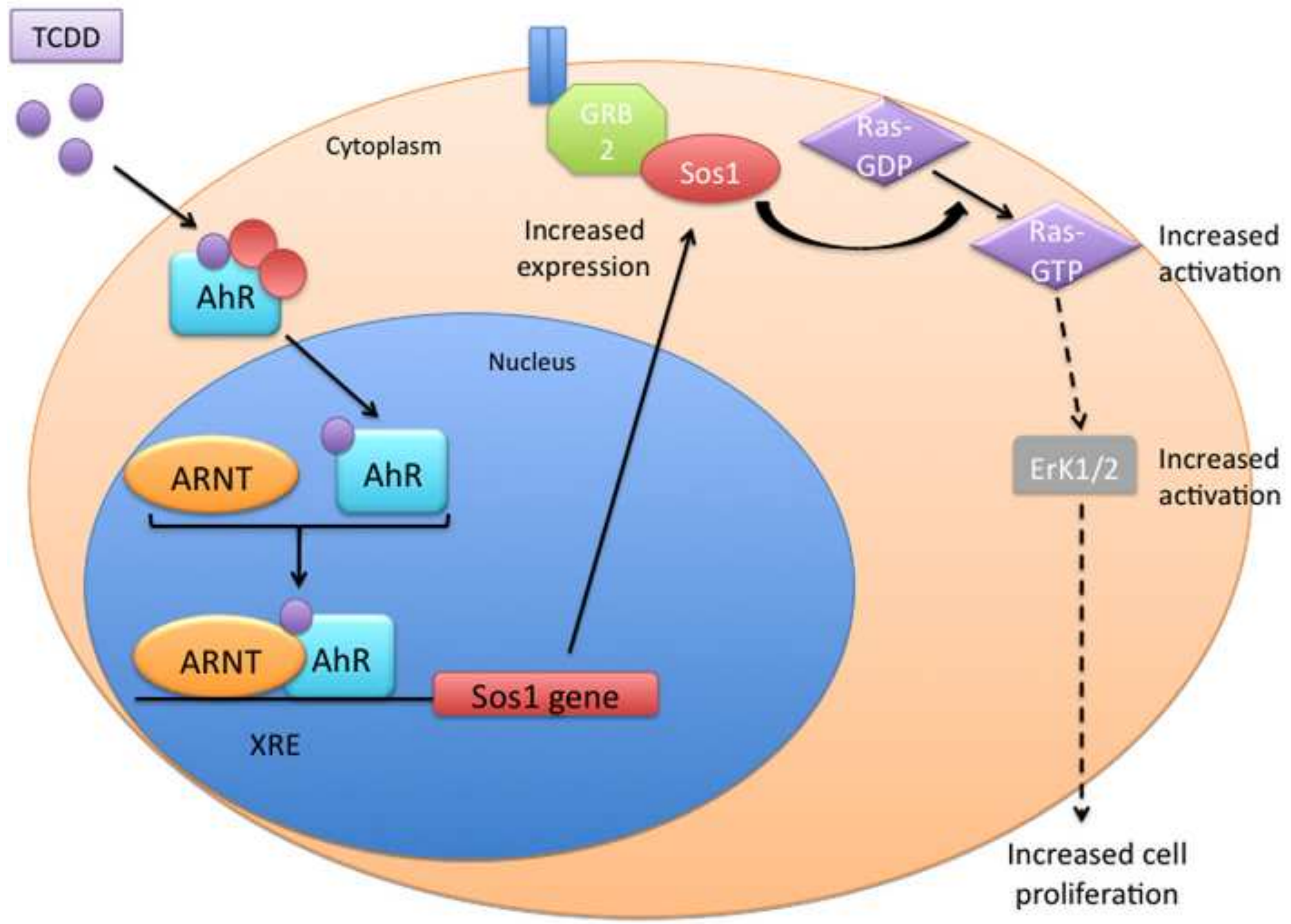

rage 30 ot 30 